ON INTELLIGENCE 
. 


\section{On Intelligence}

A Bioecological Treatise on

Intellectual Development

Expanded Edition

STEPHEN J. CECI

Harvard University Press

Cambridge, Massachusetts

London, England

1996 
Copyright $\odot 1990,1996$ by the President and Fellows of Harvard College All rights reserved

Printed in Canada

First Harvard University Press paperback edition, 1996

\section{Library of Congress Cataloging-in-Publication Data}

\section{Ceci, Stephen J.}

On intelligence: a bioecological treatise on intellectual development

/ Stephen J. Ceci. - Expanded ed.

p. cm.

Expanded ed. of: On intelligence-more or less, (C) 1990.

Includes bibliographical references and index.

ISBN 0-674-63456-X

1. Intellect. 2. Intelligence levels. 3. Nature and nurture.

I. Ceci, Stephen J. On intelligence-more or less. II. Title.

BF431.C36 $1996 \quad$ 96-23821

$153.9-\mathrm{dc} 20$

CIP 
This book is dedicated to my daughter:

Nicole Genevieve Rossiter Ceci 
